\title{
Resistance of polypropylene fibered mortar to elevated temperature under different cooling regimes
}

\author{
Resistencia del mortero con fibra de polipropileno a temperatura elevada bajo diferentes \\ regímenes de enfriamiento
}

Okan Karahan (Main Author)

Erciyes University, Civil Engineering Department, Kayseri (Turkey)

okarahan@erciyes.edu.tr

Uğur Durak (Corresponding Author)

Erciyes University, Civil Engineering Department, Kayseri (Turkey)

ugurdurak@erciyes.edu.tr

\section{Serhan Illkentapar}

Erciyes University, Civil Engineering Department, Kayseri (Turkey) serhan@erciyes.edu.tr

\section{İsmail İsa Atabey}

Nevşehir Hacı Bektaş Veli University, Civil Engineering Department, Nevşehir (Turkey) ismailatabey@nevsehir.edu.tr

\section{Cengiz Duran Atiş}

Erciyes University, Civil Engineering Department, Kayseri (Turkey)

cdatis@erciyes.edu.tr

Manuscript Code: 1341

Date of Acceptance/Reception: 01.08.2019/01.02.2019

DOI: $10.7764 / R D L C .18 .2 .386$

\begin{abstract}
Behaviour of construction materials i.e. steel, concrete and mortar under elevated temperature is important. In the study, the variations in mass loss, and strengths of polypropylene fiber reinforced mortar subjected to elevated temperatures were examined. Mortar was made with CEM I 42.5R Portland cement, monofilament polypropylene fiber, fine aggregate and drinkable water. The sand-cement and water-cement ratio were chosen 3:1 and $1: 2$ for all mixtures, respectively. Mixes containing $0,0.1,0.2$ and $0.3 \%$ polypropylene fiber in volume of solid matter of mixture were prepared. Mortars were exposed to $100,200,400,600$ and $800^{\circ} \mathrm{C}$ temperatures and cooled down $23 \pm 2^{\circ} \mathrm{C}$ in air and water. There was a difference between the temperatures at which the important reductions observed for flexural tensile and compressive strength. Significant reduction was observed at $400^{\circ} \mathrm{C}$ for compressive strength and while it was $200^{\circ} \mathrm{C}$ for flexural strength. No difference was observed between air cooling and water cooling regimes up to $600^{\circ} \mathrm{C}$; however, at $800^{\circ} \mathrm{C}$ the residual compressive and flexural strength of water cooled mortar was about $40 \%$ of the air cooled mortar. Mortar containing polypropylene fiber presented better behaviour to elevated temperature in terms of relative residual strengths up to $400^{\circ} \mathrm{C}$.
\end{abstract}

Keywords: Compressive strength, flexural strength, mortar, polypropylene fiber, high temperatura.

\begin{abstract}
Resumen
El comportamiento de los materiales de construcción, por ejemplo, acero, hormigón y mortero a temperatura elevada es importante. En el estudio, se examinaron las variaciones en la pérdida de masa y las resistencias del mortero reforzado con fibra de polipropileno sometido a temperaturas elevadas. El mortero se hizo con cemento Portland CEM I 42.5R, fibra de polipropileno monofilamento, agregado fino y agua potable. La relación arena-cemento y agua-cemento se eligió como 3: 1 y 1: 2 para todas las mezclas, respectivamente. Se prepararon mezclas que contenían 0, $0.1,0.2$ y $0.3 \%$ de fibra de polipropileno, en volumen de materia sólida de la mezcla. Los morteros se expusieron a temperaturas de $100,200,400,600$ y $800^{\circ} \mathrm{C}$ y se enfriaron $23 \pm 2{ }^{\circ} \mathrm{C}$ en aire y agua. Hubo una diferencia entre las temperaturas a las que se observaron reducciones importantes para la tracción a la flexión y resistencia a la compresión. Se observó una reducción significativa a $400^{\circ} \mathrm{C}$ para la resistencia a la compresión y mientras que fue de $200^{\circ} \mathrm{C}$ para la resistencia a la flexion No se observaron diferencias entre los regímenes de enfriamiento por aire y agua hasta $600^{\circ} \mathrm{C}$; sin embargo, a $800^{\circ} \mathrm{C}$, la resistencia residual a la compresión y a la flexión del mortero enfriado por agua era aproximadamente el $40 \%$ del mortero enfriado por aire. El mortero que contiene fibra de polipropileno presentó un mejor comportamiento a temperaturas elevadas en términos de resistencias residuales relativas hasta $400^{\circ} \mathrm{C}$
\end{abstract}


High temperature is one of the important physical deterioration parameters that effect the durability of concrete structures (Aydin, 2008). With exposure to elevated temperature, for instance during fire, concrete subjects to change in its chemical composition, physical structure, and water content (Haddad \& Shannis, 2004).

These changes take place mainly in the hardened cement paste starting from the alteration of calcium hydroxide at $400^{\circ} \mathrm{C}$ and continue till thorough decomposition of calcium-silicate-hydrate gel at about $900^{\circ} \mathrm{C}$ (Chi Sun Poon, Azhar, Anson, \& Wong, 2001b). During the last decade, extensive research has been conducted on fire resistance of concrete, and most studies emphasize on aspects such as types of aggregate, fiber addition, heating rate and maximum temperature level, testing methods, etc. (Chi Sun Poon, Azhar, Anson, \& Wong, 2001a).

Many studies indicated incorporating polypropylene fiber is an effective solution to reduce the risk of spalling of concrete or mortar subjected to high temperature (Aydin, Yazici, \& Baradan, 2008; Kalifa, Chéné, \& Gallé, 2001; Peng et al., 2006; Xiao \& Falkner, 2006; Zeiml, Leithner, Lackner, \& Mang, 2006). In case of fire, the polypropylene fibers will sublime at around $170^{\circ} \mathrm{C}$ and, create a network of micro-channels in the concrete which serve as a way to release water vapour to the atmosphere, which, will consequently prevent the types of failures referred to above (Rodrigues, Laím, \& Correia, 2010). Introducing polypropylene fiber into mixture increases the spalling resistance of concrete and mortar. However, polypropylene fibers had a negative effect on concrete's remaining mechanical properties, since they reduced the remaining compressive strength, modulus of elasticity and tensile strength of fired concrete (Sideris, Manita, \& Chaniotakis, 2009).

Poon, Shui, \& Lam (2004) concluded that using a $0.11 \%$ of polypropylene fibers by volume of mortar which increased the residual strength of concrete after exposure to $600^{\circ} \mathrm{C}$ had negative effects on the compressive strength of concrete at $800^{\circ} \mathrm{C}$. Komonen \& Penttala (2003) stated that polypropylene fiber result with a finer residual capillary pore structure in concrete reduced compressive strengths, and improved residual flexural strengths at low temperatures. Suhaendi \& Horiguchi (2006) indicated that with the melting and vaporization of its fiber constituents at $160-170^{\circ} \mathrm{C}$ and $340^{\circ} \mathrm{C}$, respectively, polypropylene fiber reinforced high strength concrete loses its mechanical and permeability performance.

On the contrary, Kalifa et al. (2001) concluded that polypropylene fibers demonstrated beneficial influence to the residual strength of concrete after exposure to high temperature. Xiao \& Falkner (2006) stated that polypropylene fiber increases the relative residual compressive strength, but decrease the residual flexural strength. Chan, Luo, \& Sun (2000) reported that the inclusion of polypropylene fiber did not cause a significant decrease in residual strength compared to without fibers. Behnood \& Ghandehari (2009) concluded that the splitting tensile strength of concrete was more sensitive to high temperatures than the compressive strength, and the presence of polypropylene fiber was more effective for compressive strength than splitting tensile strength above $200 \circ \mathrm{C}$. Also, they concluded that the addition of polypropylene fibers could significantly promote the residual mechanical properties of high strength concrete during heating. Noumowe (2005) stated that the addition of polypropylene fibers $(0.2 \%)$ may cause small changes in remaining compressive strength, elasticity module and splitting tensile strength owing to fibers melting during heating up to $200^{\circ} \mathrm{C}$. Tanyildizi (2009) attributed the reduction in compressive and flexural strength to the drying out free water and fraction water of hydration of concrete due to high temperatures.

Yermak, Pliya, Beaucour, Simon, \& Noumowé (2017) studied on effect of steel and polypropylene fibers on the behaviour of concrete subjected to elevated temperature in terms of spalling, transfer and mechanical properties of concrete. Strength grade of concrete was $70 \mathrm{MPa}$. They reported that high strength concrete containing $60 \mathrm{~kg} / \mathrm{m}^{3} \mathrm{of}$ steel fiber showed spalling however control concrete and concrete made with combination of polypropylene fiber $(0.75$ $\left.\mathrm{kg} / \mathrm{m}^{3}\right)$ and stell fiber $\left(60 \mathrm{~kg} / \mathrm{m}^{3}\right)$ did not spall. They concluded that using polypropylene fiber increase the porosity and permeability of concretes thus resulting with higher spalling resistance.

Hiremath \& Yaragal (2018) carried out laboratory study to investigate and evaluate the performance of reactive concrete containing polypropylene fibers subject to high temperatures from $200{ }^{\circ} \mathrm{C}$ to $800{ }^{\circ} \mathrm{C}$. Fiber dosages were from $0.1 \%$ to $0.9 \%$. Residual compressive strength of reactive powder concrete and concrete containing fiber were measured. In addition, ultrasonic pulse velocity and water absorption and sorptivity of samples were measured. Based on their experimental result, they concluded that inclusion of $0.1 \%$ fiber dosage was adequate to control spalling of RPC up to $800^{\circ} \mathrm{C}$. They recommended that utilization of $0.5 \%$ fiber in reactive powder concrete to enhance the residual properties. They also evaluated microstructural properties (formation of pores and cracks) of reactive powder concrete. This assessment of reactive powder concrete show that quantity of hydrated products increase and microstructural formation of reactive powder concrete gets denser up to $400^{\circ} \mathrm{C}$. However, when exposure temperature reaches to $600^{\circ} \mathrm{C}$, concrete starts to deteriorate while its hydrated products decompose. 
Li, Pimienta, Pinoteau, \& Tan (2019) researched the individual and combined influence of polypropylene fibers, steel fibers, and size of aggregate on spalling behavior and pore pressure development of very-high-performance concrete subjected to high temperature. They measured compressive, tensile, and permeability properties of specimens to asses spalling behavior. It is reported that inclusion of polypropylene fibers in mixture prevented spalling, and they found to be more effective in increasing permeability than steel fibers and larger aggregates. However, combined effect of using polypropylene fibers and steel fibers, and polypropylene fibers and larger aggregates result with higher permeability than that of inclusion of individual polypropylene fibers.

Amancio, De Carvalho Rafael, De Oliveira Dias, \& Bezerra Cabral (2018) exposed concrete reinforced with polypropylene fibers to elevated temperature from $200 \mathrm{C}$ to $800^{\circ} \mathrm{C}$. They produced $30 \mathrm{MPa}$ concrete grade with the inclusion of three different fiber amounts $\left(1.2,1.8\right.$ and $\left.2.4 \mathrm{k} / \mathrm{m}^{3}\right)$. The properties measured were compressive strength, ultrasonic pulse velocity, and mass reduction. In comparison to mixture without fiber, spalling resistance of concrete was increased when polypropylene fiber included in the mixture up to exposure temperature of $600^{\circ} \mathrm{C}$. They noted that residual strength of the concrete is not influenced by the inclusion of fibers when concrete is exposed to elevated temperature.

The literature survey indicated that conflict still exists regarding the use of polypropylene and its influence on fire resistance of concrete or mortar. Also, few studies have examined the cooling regimes of concrete or mortar subjected to elevated temperatures. Therefore, the aims of this study were to investigate the influence of elevated temperature and cooling regimes on compressive and particularly flexural strength of mortar containing polypropylene fiber. This was achieved by measuring mass loss, residual flexural and compressive strength of mortar made with and without polypropylene fiber, after elevated temperature followed by air and water cooling.

\section{Materials and methods}

The binding material used throughout this study was ordinary Portland Cement CEM I 42.5R complying with TS EN 1971 (TS EN 197-1, 2012). The chemical composition of the cement is shown in Table 1.

\begin{tabular}{cccc}
\multicolumn{4}{c}{ Table 1. Chemical composition of cement. Source:Self-Elaboration. } \\
\hline Oxide & $(\%)$ & Oxide & $(\%)$ \\
\hline $\mathrm{CaO}$ & 62.1 & $\mathrm{SO}_{3}$ & 3.4 \\
$\mathrm{SiO}_{2}$ & 21.2 & $\mathrm{Cl}$ & 0.01 \\
$\mathrm{Al}_{2} \mathrm{O}_{3}$ & 5.6 & $\mathrm{Na}_{2} \mathrm{O}$ & 0.4 \\
$\mathrm{Fe}_{2} \mathrm{O}_{3}$ & 3.2 & $\mathrm{~K}_{2} \mathrm{O}$ & 0.9 \\
$\mathrm{MgO}$ & 1.6 & $\mathrm{~F} . \mathrm{CaO}$ & 0.8 \\
\hline
\end{tabular}

In preparation of mortar mixture, natural river sand was used. The sand used was quartzite sand. Maximum size of the sand was $4 \mathrm{~mm}$. Absorption value was 1.9\%. Relative density of sand at saturated surface dry (SSD) condition was 2.63 . The fine aggregate had fineness modulus of 2.61. The gradation of sand obtained in accordance with TS EN 933-1 (TS EN 933-1, 2012) is presented in Table 2.

Table 2. Grading of fine aggregate. Source: Self-Elaboration.

\begin{tabular}{lccccc}
\multicolumn{6}{c}{ Table 2. Grading of fine aggregate. Source: Self-Elaboration. } \\
\hline Sieve size (mm) & 4 & 2 & 1 & 0.5 & 0.25 \\
\hline Passing (\%) & 99.4 & 64.7 & 37.6 & 23.7 & 13.8 \\
\hline
\end{tabular}

Polypropylene fibers used were fire (type M6) monofilament fibers with a length of $6 \mathrm{~mm}$ and diameter of $18 \mu \mathrm{m}$. The characteristic properties of polypropylene fiber are presented in Table 3.

Table 3. Characteristic of polypropylene fiber. Source: Self-Elaboration.

\begin{tabular}{cccccc}
\multicolumn{6}{c}{ Table 3. Characteristic of polypropylene fiber. Source: Self-Elaboration. } \\
\hline Density $\left(\mathrm{kg} / \mathrm{dm}^{3}\right)$ & Length $(\mathrm{mm})$ & Diameter $(\mu \mathrm{m})$ & Aspect ratio & $\begin{array}{c}\text { Tensile } \\
\text { strength } \\
\left(\mathrm{N} / \mathrm{mm}^{2}\right)\end{array}$ & $\begin{array}{c}\text { E-module } \\
\left(\mathrm{N} / \mathrm{mm}^{2}\right)\end{array}$ \\
\hline 0.91 & 6 & 18 & 3000 & 300 & 3500 \\
\hline
\end{tabular}


Four types of mixtures were prepared. Mortar mixtures were proportioned according to the TS EN 196-1 (TS EN 196-1, 2016) mix design procedure for mortar at a sand/cement ratio $3: 1$ and water/cement ratio 1:2 with fine aggregate, Portland cement, and natural spring water. Fresh fiber reinforced mortars containing 0\% (M0), 0.1\% (M1), 0.2\% (M2) and $0.3 \%(\mathrm{M} 3)$ polypropylene fiber in volume of solid matter of mixture were prepared. The ingredients of mixtures for three $40 \times 40 \times 160 \mathrm{~mm}^{3}$ prismatic specimens are presented in Table 4.

All mortar mixtures were produced in a Hobart mixer. The mixing procedures for mortar involved the following steps. The water, cement and polypropylene fiber was put in a mixer and mixed in slow mode for 30 seconds. The sand was introduced in 30 seconds, whilst mixing was in slow mode. Then, the mixture was mixed in fast mode for 30 seconds. The mixture was waited for 15 seconds without mixing. The mixture was mixed for a further one minute in fast mode (TS EN 196-1, 2016).

\begin{tabular}{ccccccc}
\multicolumn{7}{c}{ Table 4. Mix design of all mixtures. Source: Self-Elaboration. } \\
\hline Mix & $\begin{array}{c}\text { Fiber } \\
(\mathrm{g})\end{array}$ & $\begin{array}{c}\text { Cement } \\
(\mathrm{g})\end{array}$ & $\begin{array}{c}\text { Sand } \\
(\mathrm{g})\end{array}$ & $\begin{array}{c}\text { Water } \\
(\mathrm{g})\end{array}$ & $\begin{array}{c}\text { Flow } \\
(\mathrm{mm})\end{array}$ & $\begin{array}{c}\text { Unit } \\
\text { Weight } \\
\left(\mathrm{g} / \mathrm{cm}^{3}\right)\end{array}$ \\
\hline M0 & 0 & 450 & 1350 & 225 & 168 & 2.06 \\
M1 & 0.8 & 450 & 1350 & 225 & 161 & 2.04 \\
M2 & 1.6 & 450 & 1350 & 225 & 154 & 2.00 \\
M3 & 2.4 & 450 & 1350 & 225 & 143 & 1.99 \\
\hline
\end{tabular}

After mixing, mortar workability was measured as an indicator of mixture consistency with mortar flow test. Fresh mixture was poured into a small frustum cone on its vibrating table according to description made in TS EN 1015-3 (TS EN 1015-3, 2000), and the cone was taken off. Fresh mortar was jolted from $12.5 \mathrm{~mm}$ height for 15 times in 15 seconds onto the vibrating table. Afterward, the mortar spread, and the maximum spread was measured. The average of two values of spread diameter was recorded. The hardened unit weight of polypropylene fiber reinforced mortar was between $1.99-2.04 \mathrm{~g} / \mathrm{cm}^{3}$. The results of unit weight and consistency of fresh mortar by flow table are presented in Table 4. It shows that as the polypropylene fiber's content increased in mortar, unit weight and workability of mixture decreased.

Then mortars were cast into three-cell prismatic $40 \times 40 \times 160 \mathrm{~mm}^{3}$ steel moulds and vibrated for compaction. Three prismatic specimens per mixture were cast in steel moulds. The specimens were kept in the moulds for 24 hours at $23 \pm 2^{\circ} \mathrm{C}$ temperature. After demoulding, the specimens were stored in water at $21 \pm 1^{\circ} \mathrm{C}$ for 28 days. Table 5 shows the detail of the variables used in the experiment.

Table 5. Testing variables used in the experiments. Source: Self-Elaboration.

\begin{tabular}{ccc}
\hline Heating degree $\left({ }^{\circ} \mathrm{C}\right)$ & Polypropylene (\%) & Cooling regime \\
\hline $20,100,200,400,600,800$ & $0,0.1,0.2,0.3$ & In air, In water \\
\hline
\end{tabular}

The elevated temperature test was carried out in a Protherm electric oven (Figure 2). At 28 days, the specimens were taken out curing tank, and dried at $105^{\circ} \mathrm{C}$ for 24 hours for avoiding undesirable explosive spalling of concrete while subjected to high temperatures above $100^{\circ} \mathrm{C}$ (Peng et al., 2006). Dried specimens were placed in an electrical furnace with heat applied at a rate of $12^{\circ} \mathrm{C} / \mathrm{min}$ until the desired temperature was reached. Target desired temperatures were set at five values, $100,200,400,600$ and $800^{\circ} \mathrm{C}$. After having reached a target temperature, the temperature was maintained for 1 hour. Then, mortar samples subjected to high temperature were cooled down in two regimes. Some specimens were remained in laboratory conditions for ambient cooling untill cool down room temperature. Temperature variations versus time were plotted and presented in Figure 1. Other group of samples was shockly cooled by exposing to water at $23 \pm 2^{\circ} \mathrm{C}$ for one hour. After cooling, mass loss of samples, flexural tensile strength and compressive strength were measured. Mass of specimens were weighed before and after exposure to elevated temperatures. 


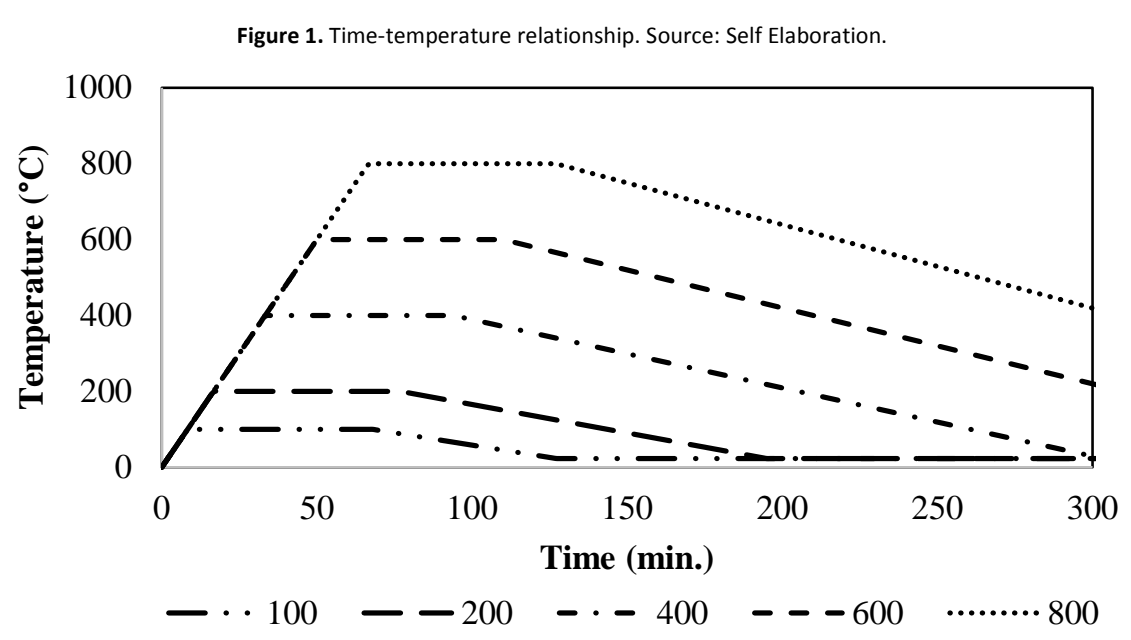

Compressive and flexural tensile strengths were measured according to TS EN 1015-11 (TS EN 1015-11, 2000). Using $40 \times 40 \times 160 \mathrm{~mm}^{3}$ sized prism samples, flexural strength test was made, whereas compressive strength test was measured on broken prismatic specimens. Test results were compared with results of mortar specimens tested for other mixes, temperatures and cooling regimes.

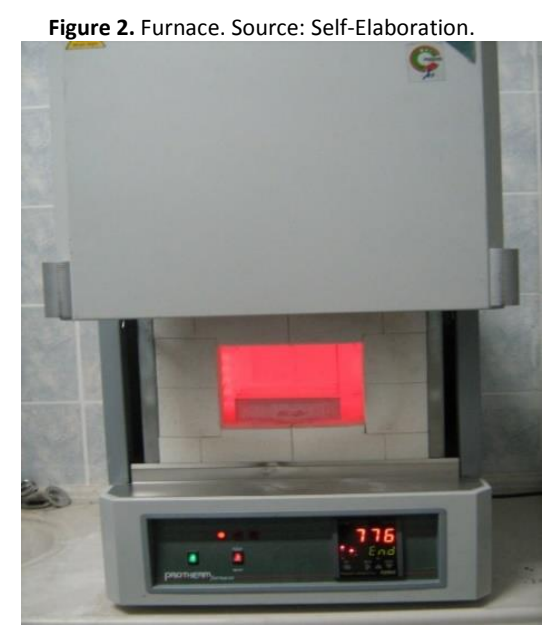

The effect of polypropylene dosage at elevated temperature on behaviour of mortars for both air and water cooling were investigated using mortar specimens containing $0,0.1,0.2$ and $0.3 \%$ polypropylene fiber. The hardened mortar samples were tested at 28 days.

The results of specimens exposed to elevated temperatures were compared with an unheated control specimen. The measured properties of mortar were mass loss, flexural tensile and compressive strength. Figure 3 . illustrates the mortars (with and without polypropylene fiber) surfaces after exposure to $800 \circ \mathrm{C}$ temperatures in water cooling (Karahan, 2010).

The mass of hardened mortar samples were determined before and after heating at target temperatures. Standard deviation for each mass loss results data point is calculated and average standard deviations are found to be in the order of $2 \%$ and $4 \%$, for air and water cooled specimens, respectively. The relative mass losses of all the investigated mixtures are shown in Figure 4 and Figure 5 as an average of three specimens. Mass loss increases as target heating temperature increases. Figure 4 and Figure 5 show that the mass loss of mortar containing polypropylene fiber tends to increase in comparison to mortar made without polypropylene fiber. 

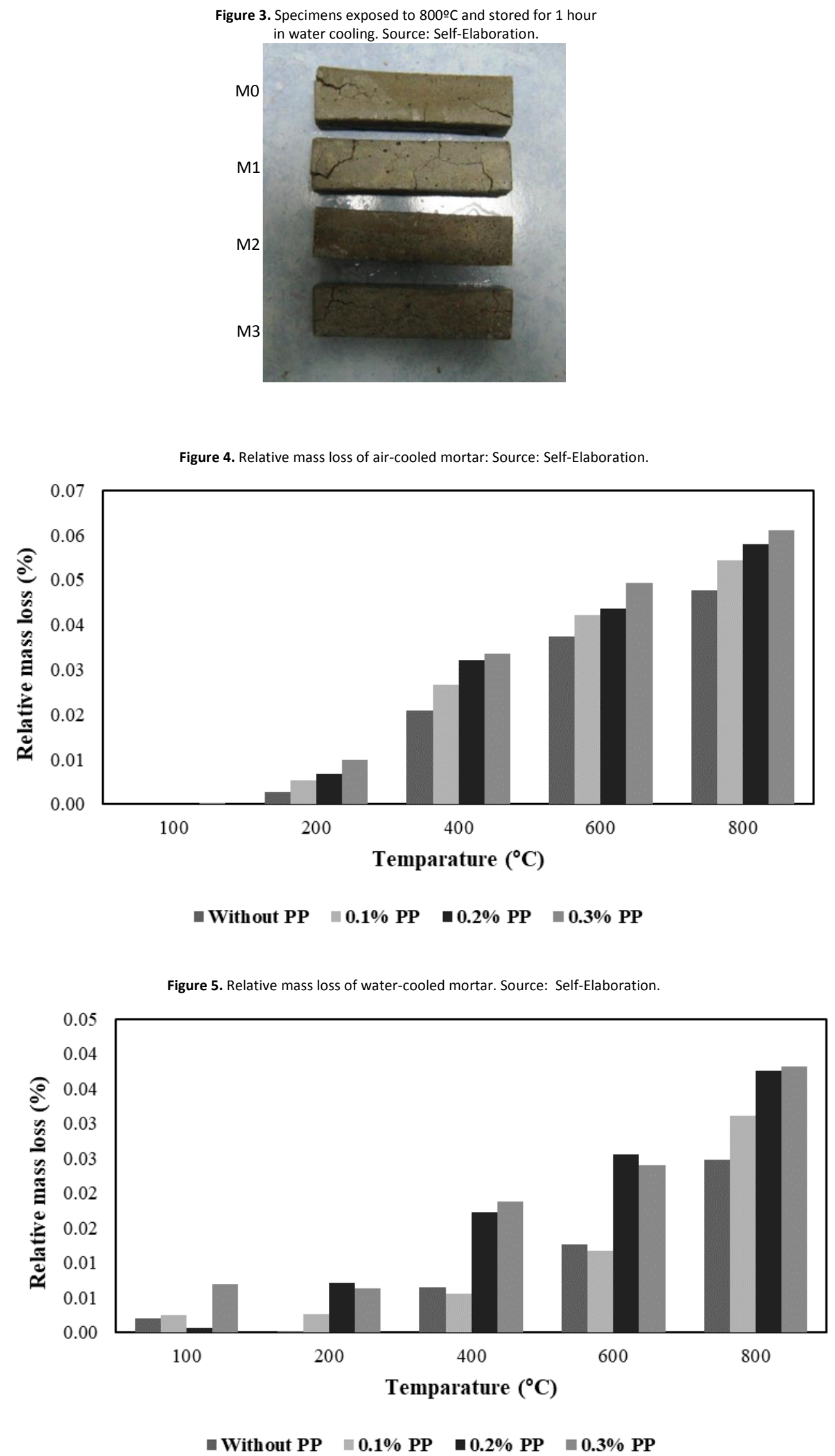

From both figures, it can be concluded that increasing polypropylene content in mortar increases mass loss of mortar. For both cooling regimes, mass loss of mortar is insignificant when exposure temperature was 200 ㄷ $\mathrm{C}$ or below. The percentages of mass losses were about $2-3$ and $4-5$ and $5-6$ for air cooling at 400,600 and $800^{\circ} \mathrm{C}$, respectively. The 
percentages of mass losses were about $1-2$ and $1-2$ and 2 - 4 for water cooling at 400,600 and $800^{\circ} \mathrm{C}$, respectively. It was observed that the mass loss of air cooling was found to be higher than the mass loss of water cooling. This was attributed to rehydration of $\mathrm{CaO}$ which was formed due to dehydration of $\mathrm{Ca}(\mathrm{OH})_{2}$ in mortar after heating, thus, this $\mathrm{CaO}$ hydrates with water when the mortar was cooled down in water. Rehydration of $\mathrm{CaO}$ bounds water and increases the mass of sample. It should be noted that the mass loss of mortar measured in this study was total mass loss which is caused by released water and melted polypropylene fiber. This results was in agreement with the published results of Xiao \& Falkner (2006), Rodrigues et al. (2010), Arioz (2007) who concluded that the mass of the specimens reduced significantly as the temperature increased.

Compressive strength results for reference control unheated mortar and mortar subjected to elevated temperature are presented in Table 6. In general, it can be observed from Table 6 that the higher peak temperature results in higher reduction in compressive strength. The decrease in the compressive strength of heated mortar was found to be insignificant up to $200^{\circ} \mathrm{C}$, when compared to unheated control mortar regardless of polypropylene content and cooling regimes. However, the decrease in the compressive strength of mortars were found to be significant at $400^{\circ} \mathrm{C}$ elevated temperature, and the reduction seemed to be dramatic at $600^{\circ} \mathrm{C}$. This is explained by the well known fact that $\mathrm{Ca}(\mathrm{OH})_{2}$ decomposes to $\mathrm{CaO}$ above $400-600^{\circ} \mathrm{C}$. The order of the reduction in compressive strength was found to be at about $50 \%$ at $600^{\circ} \mathrm{C}$. The comparison made between cooling regimes showed that there was no difference between the cooling regimes in terms of residual compressive strength of mortar regardless of polypropylene fiber content, up to $600^{\circ} \mathrm{C}$ elevated temperature. Therefore, water cooling or extinguishing fire with water can be performed for a small-scale fire.

Table 6. Compressive strength of hardened mortar (MPa). Source: Self-Elaboration.

\begin{tabular}{cccccccc}
\hline Mix & $\begin{array}{c}\text { Rooling } \\
\text { Regime }\end{array}$ & $20^{\circ} \mathrm{C}$ & $100^{\circ} \mathrm{C}$ & $200^{\circ} \mathrm{C}$ & $400^{\circ} \mathrm{C}$ & $600^{\circ} \mathrm{C}$ & $800^{\circ} \mathrm{C}$ \\
\hline M0 & Air & 64.7 & 64.5 & 65.7 & 54.2 & 33.5 & 15.2 \\
M1 & Air & 56.7 & 56.1 & 59.9 & 53.0 & 31.3 & 14.1 \\
M2 & Air & 57.2 & 59.8 & 61.1 & 50.3 & 27.3 & 13.4 \\
M3 & Air & 59.1 & 58.8 & 60.5 & 49.0 & 28.9 & 11.0 \\
M0 & Water & 64.7 & 65.7 & 60.0 & 49.8 & 31.1 & 6.4 \\
M1 & Water & 56.7 & 60.7 & 60.5 & 52.2 & 30.9 & 5.0 \\
M2 & Water & 57.2 & 57.7 & 59.1 & 47.5 & 30.0 & 4.5 \\
M3 & Water & 59.1 & 60.9 & 58.1 & 49.2 & 29.9 & 4.3 \\
\hline
\end{tabular}

Figure 6 and 7 compare the relative residual compressive strengths corresponding to mortar with polypropylene content to exposure temperatures with cooling regimes. The relative residual strength is defined as the ratio of compressive strength at high temperature to its initial compressive strength at ambient temperature. Obviously regardless of the presence of polypropylene fibers, water cooling resulted higher strength reduction when compared to air cooling regime. The influence of water cooling on the reduction of compressive strength becomes more marked at $800^{\circ} \mathrm{C}$.

A comparison between air cooling and water cooling regimes at $800^{\circ} \mathrm{C}$ showed that remaining compressive strength of water cooled mortar was lower than half of the compressive strength of air cooled mortar (at average $40 \%$ ). Therefore, the water cooling method or fire extinguishing with water sprinkling is not suitable for fire with longer duration or a large-scale fire. Yüzer, Aköz, \& Öztürk (2004) made a similar recommendation stating that alternative extinguishers should be used instead of water. 


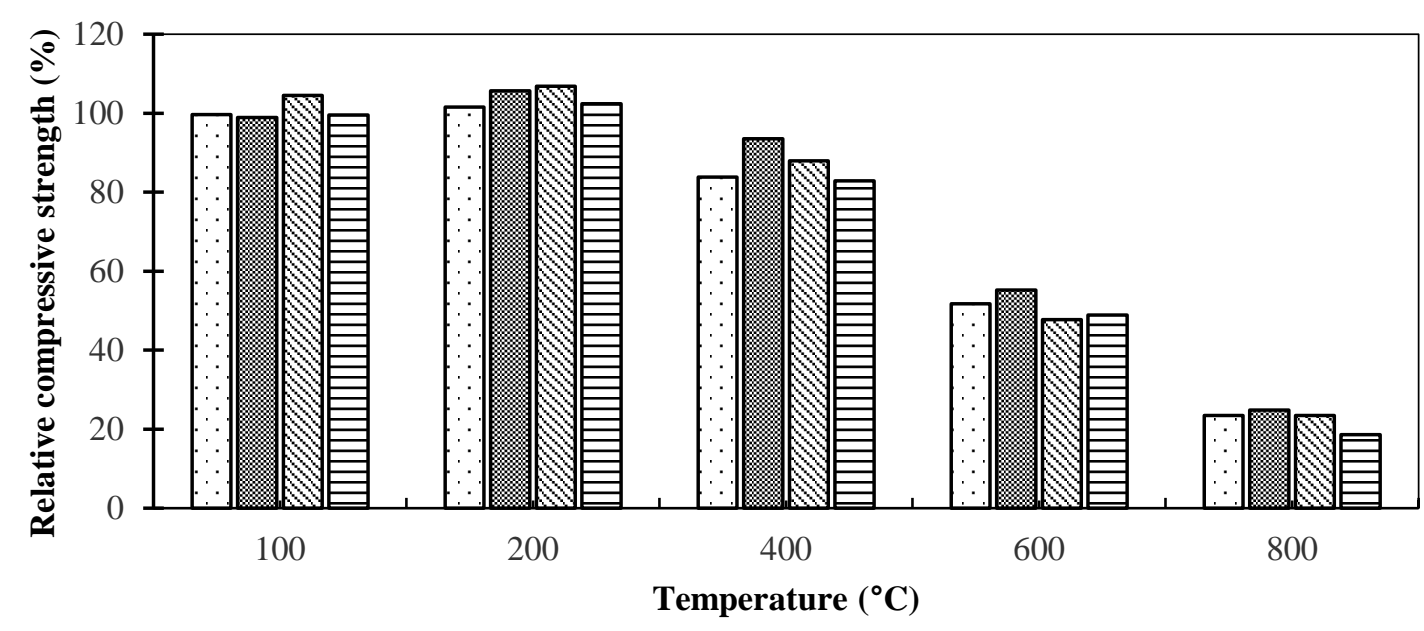

口Without PP $\mathbf{0} 0.1 \%$ PP $\mathbf{\$} 0.2 \%$ PP $\quad$ 日 $0.3 \%$ PP

Figure 7. Relative compressive strength of water cooled mortar. Source: Self-Elaboration.

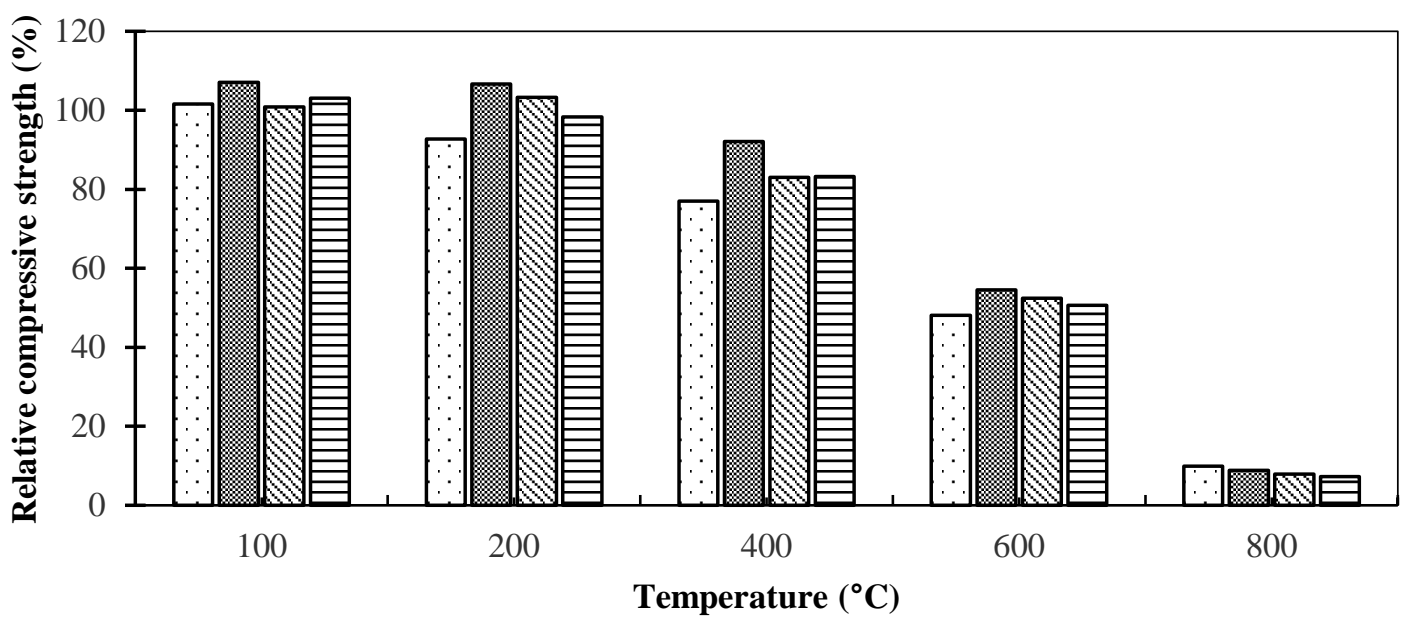

口Without PP $\mathbf{0} 0.1 \%$ PP $0.2 \%$ PP $\quad \mathbf{9} 0.3 \%$ PP

Overall, a comparison was made whether the polypropylene influenced the compressive strength of mortar before and after elevated temperature, little decrease in compressive strength was observed when the polypropylene fiber content of mortar increased for both cooling regimes irrespective of heating temperature. However, when comparison was made interms of relative changes in compressive strength to control mortar, influence of fiber addition in mortar show that better behaviour at $200^{\circ} \mathrm{C}$ and $400^{\circ} \mathrm{C}$ regardless of cooling method. Moreover, at $600^{\circ} \mathrm{C}$ and $800^{\circ} \mathrm{C}$, mortar containing polypropylene was behaved similar to control mortar. Xiao \& König (2004) reported that the compressive strength of high strength concrete made with and without polypropylene fiber was almost the same after high temperature, regardless of the elevated temperatures. Aydin et al. (2008) reported that using polypropylene fiber decreased the compressive strength due to melting of polypropylene. Karahan (2010) studied on residual compressive strength of damaged mortar after elevated temperature, he concluded that slow cooling method either in air or in oven represented almost no difference in terms of compressive strength reduction for all exposure temperatures, however, quick cooling in water created important decrease in compressive strength in comparison to other gradual air cooling and furnace cooling method.

Flexural tensile strength results for reference control, unheated mortar and mortar subjected to elevated temperature are presented in Table 7. In general, similar to the compressive strength results, it can be observed from Table 7 that the higher peak temperature results in a higher reduction in flexural strength. The variations of relative remaining flexural tensile strength ratio of mortar samples after exposure to high temperature are shown in Figure 8 and 9. 
It can be seen from Figure 8 and 9, as opposed to compressive strength, the strength reduction becomes significant at $200^{\circ} \mathrm{C}$ for flexural tensile strength when a specimen was cooled in water; (this may be due to formation of cracks when heated specimens introduced to water for shock cooling) in an air cooled specimen the strength reduction was insignificant. In addition, the reduction in the flexural strength of mortar was about $21-36 \%$ for air cooling, 45-62\% for water cooling at $400^{\circ} \mathrm{C}$. It was about $70-78 \%$ for air cooling, $72-87 \%$ for water cooling at $600^{\circ} \mathrm{C}$. A comparison between air cooling and water cooling regimes at $800^{\circ} \mathrm{C}$ shows that residual flexural tensile strength of water cooled mortar was found to be half of the flexural tensile strength value of air cooled mortar.

\begin{tabular}{cccccccc}
\multicolumn{7}{c}{ Table 7. Flexural tensile strength of hardened mortar (MPa). Source: Self-Elaboration. } \\
\hline Mix & $\begin{array}{c}\text { Cooling } \\
\text { Regime }\end{array}$ & $20^{\circ} \mathrm{C}$ & $100^{\circ} \mathrm{C}$ & $200^{\circ} \mathrm{C}$ & $400^{\circ} \mathrm{C}$ & $600^{\circ} \mathrm{C}$ & $800^{\circ} \mathrm{C}$ \\
\hline M0 & Air & 6.4 & 5.9 & 6.3 & 4.1 & 1.9 & 1.2 \\
M1 & Air & 5.6 & 5.1 & 5.2 & 4.5 & 1.7 & 0.9 \\
M2 & Air & 5.7 & 5.5 & 6.3 & 4.5 & 1.4 & 0.7 \\
M3 & Air & 6.0 & 5.9 & 6.6 & 4.1 & 1.3 & 0.3 \\
M0 & Water & 6.4 & 5.8 & 4.8 & 3.1 & 1.8 & 0.6 \\
M1 & Water & 5.6 & 5.4 & 4.5 & 3.1 & 1.4 & 0.4 \\
M2 & Water & 5.7 & 5.6 & 4.1 & 2.9 & 1.3 & 0.3 \\
M3 & Water & 6.0 & 5.8 & 4.0 & 2.3 & 0.8 & 0.3 \\
\hline
\end{tabular}

Figure 8. Relative flexural strength of air cooled mortar. Source: Self-Elaboration.

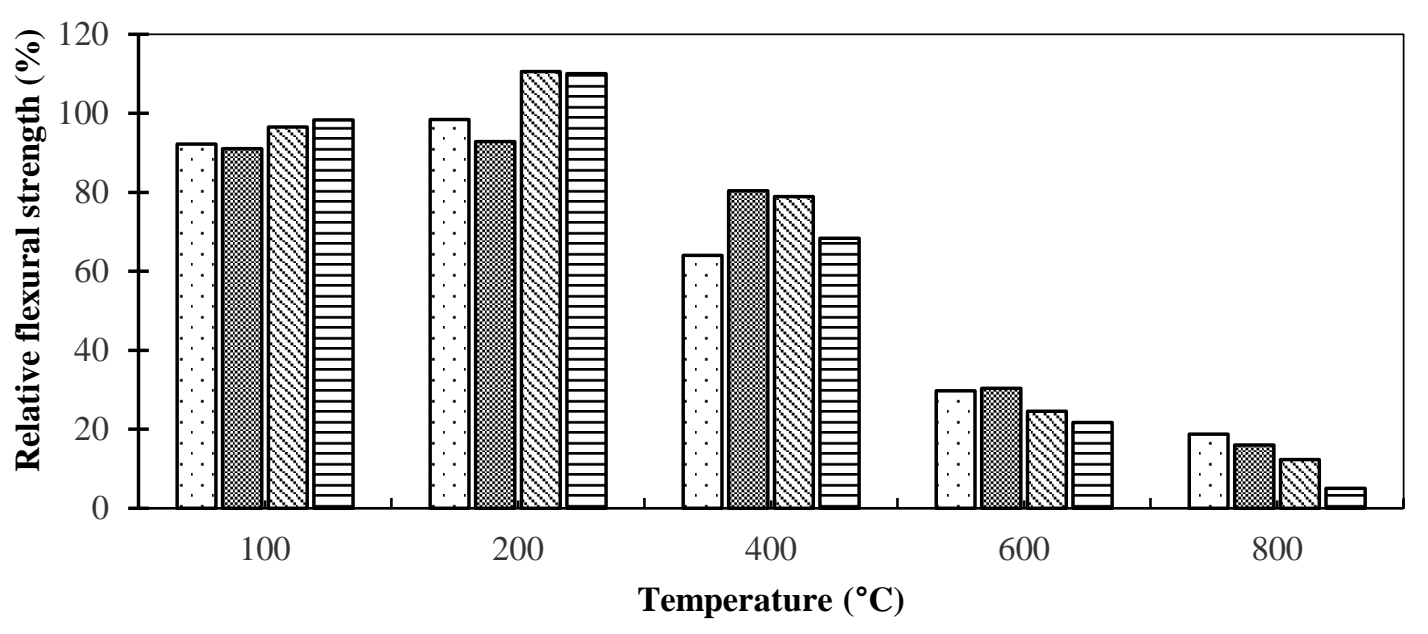

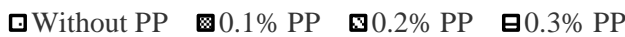

An overall observation showed that the inclusion of polypropylene in the mortar mixture did not increase the residual flexural strength of mortar made with type M6 polypropylene used at 0, 0.1, 0.2 and $0.3 \%$ fiber volume content. Flexural tensile strength was influenced more than that of the compressive strength, due to elevated temperature which was attributed to the fine cracks that occurred with the rapid heating and cooling period. Additional comparison was made in terms of tensile strength rate to compressive strength; the comparison showed that while temperature increases the strength rate reduces. However, this rate tends to reduce for mortar made with polypropylene fiber in comparison to control mortar. This result was found to be valid for both cooling methods. 


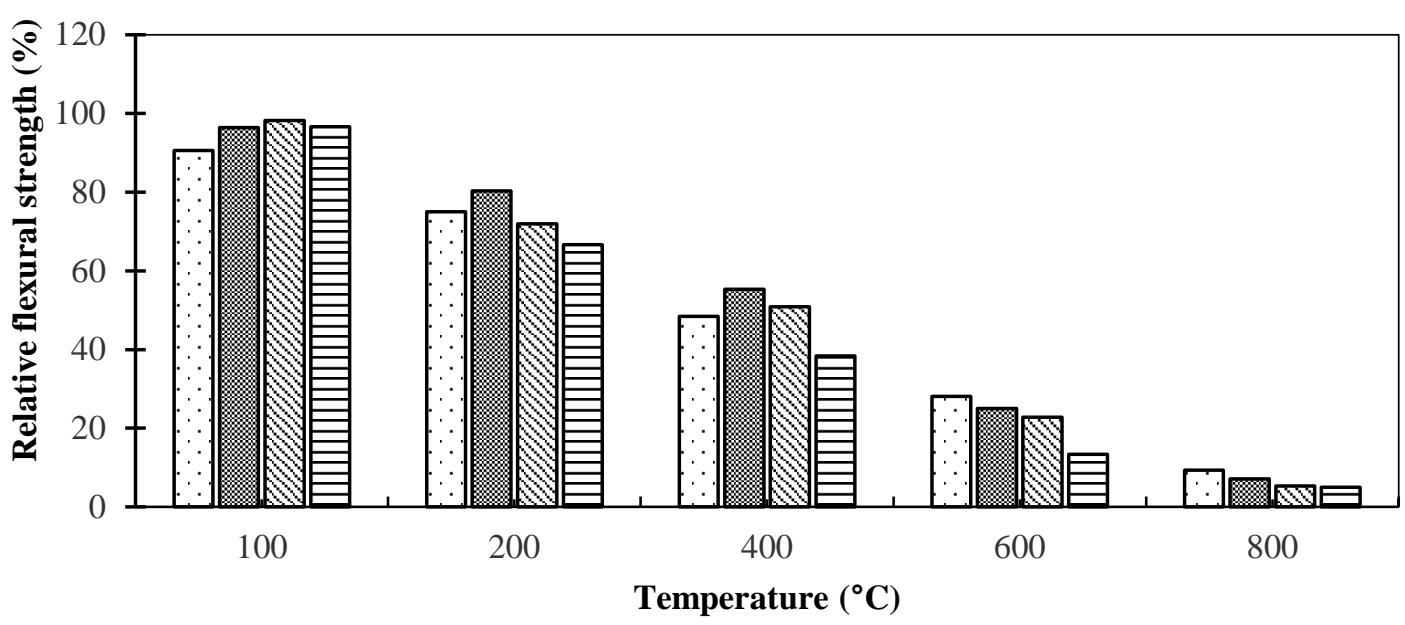

口Without PP $0.1 \%$ PP $\mathbf{0} 0.2 \%$ PP $\quad$ 日 $0.3 \%$ PP

This finding agrees with the published literature by Behnood \& Ghandehari (2009) who concluded that the splitting tensile strength of concrete was more sensitive to high temperature than the compressive strength was. Furthermore, Xiao \& Falkner (2006) concluded that the residual flexural strength of concrete with and without polypropylene fibers drops continuously under rising temperature. Aydin et al. (2008) reported that the deteriorating effect of elevated temperatures on flexural strength of mortar specimens was more extreme than compressive strength. Also, the other researches claimed that, the devastating effect of micro-cracks that form at elevated temperatures was more visible in the case of tensile stress created in flexural test (Cülfik \& Özturan, 2002).

\section{Conclusion}

- $\quad$ The mass loss of air cooling was found to be higher than the mass loss of water cooling. This was attributed to rehydration of $\mathrm{CaO}$ which was formed due to dehydration of $\mathrm{Ca}(\mathrm{OH})_{2}$ in mortar after elevated temperature, thus, this $\mathrm{CaO}$ hydrates with water when the mortar was cooled down in water. Rehydration of $\mathrm{CaO}$ bounds water and increases mass of sample.

- A small decrease in compressive strength was observed when the polypropylene fiber inclusion in mortar. The reduction in the compressive strength of heated mortar was insignificant up to $200^{\circ} \mathrm{C}$. Besides that the decrease in the compressive strength of mortar was found to be significant at $400^{\circ} \mathrm{C}$ elevated temperature, and the reduction seemed to be dramatic at $600^{\circ} \mathrm{C}$. The order of the reduction in compressive strength was found to be at about $50 \%$ at $600^{\circ} \mathrm{C}$. In addition, interms of relative changes in compressive strength, polypropylene fiber mortar behaved better than control mortar mixture did at up to $400^{\circ} \mathrm{C}$.

- Contrary to compressive strength, the flexural tensile strength reduction became significant at $200^{\circ} \mathrm{C}$. In addition, the reduction in the flexural strength of mortar was about $21-36 \%$ for air cooling, $45-62 \%$ for water cooling at $400^{\circ} \mathrm{C}$. It was about $70-78 \%$ for air cooling, $72-87 \%$ for water cooling at $600^{\circ} \mathrm{C}$.

- $\quad$ Flexural tensile strength was influenced more than the compressive strength due to elevated temperature which was attributed to fine cracks. This may be owing to the fact that, the harmful effect of micro cracks that form at high temperatures was more apparent in the case of tensile stress.

- $\quad$ Based on laboratory work, addition of $0.1 \%$ polypropylene fiber in mixture was found to be optimum rate regardless of compressive or tensile strength, for both air and water cooling regimes.

- It was observed that water cooling result in more strength reduction when compared to an air cooling regime at $800^{\circ} \mathrm{C}$. Therefore, the influence of water cooling in the reduction of compressive strength becomes more marked at higher temperatures. 
Amancio, F. A., De Carvalho Rafael, M. F., De Oliveira Dias, A. R., \& Bezerra Cabral, A. E. (2018). Behavior of concrete reinforced with polypropylene fiber exposed to high temperatures. Procedia Structural Integrity, 11, 91-98. https://doi.org/10.1016/j.prostr.2018.11.013

Arioz, O. (2007). Effects of elevated temperatures on properties of concrete. Fire Safety Journal. https://doi.org/10.1016/j.firesaf.2007.01.003

Aydin, S. (2008). Development of a high-temperature-resistant mortar by using slag and pumice. Fire Safety Journal, 43(8), 610-617. https://doi.org/10.1016/j.firesaf.2008.02.001

Aydin, S., Yazici, H., \& Baradan, B. (2008). High temperature resistance of normal strength and autoclaved high strength mortars incorporated polypropylene and steel fibers. Construction and Building Materials. https://doi.org/10.1016/j.conbuildmat.2006.11.003

Behnood, A., \& Ghandehari, M. (2009). Comparison of compressive and splitting tensile strength of high-strength concrete with and without polypropylene fibers heated to high temperatures. Fire Safety Journal. https://doi.org/10.1016/j.firesaf.2009.07.001

Chan, S. Y. N., Luo, X., \& Sun, W. (2000). Effect of high temperature and cooling regimes on the compressive strength and pore properties of high performance concrete. Construction and Building Materials. https://doi.org/10.1016/S0950-0618(00)00031-3

Cülfik, M. S., \& Özturan, T. (2002). Effect of elevated temperatures on the residual mechanical properties of high-performance mortar. Cement and Concrete Research, 32(5), 809-816. https://doi.org/10.1016/S0008-8846(02)00709-3

Haddad, R. H., \& Shannis, L. G. (2004). Post-fire behavior of bond between high strength pozzolanic concrete and reinforcing steel. Construction and Building Materials, 18(6), 425-435. https://doi.org/10.1016/j.conbuildmat.2004.03.006

Hiremath, P. N., \& Yaragal, S. C. (2018). Performance evaluation of reactive powder concrete with polypropylene fibers at elevated temperatures. Construction and Building Materials, 169, 499-512. https://doi.org/10.1016/j.conbuildmat.2018.03.020

Kalifa, P., Chéné, G., \& Gallé, C. (2001). High-temperature behaviour of HPC with polypropylene fibres - From spalling to microstructure. Cement and Concrete Research. https://doi.org/10.1016/S0008-8846(01)00596-8

Karahan, O. (2010). Residual compressive strength of fire-damaged mortar after post-fire-air-curing. FIRE AND MATERIALS, (2), 561-567. https://doi.org/10.1002/fam

Komonen, J., \& Penttala, V. (2003). Effects of high temperature on the pore structure and strength of plain and polypropylene fiber reinforced cement pastes. Fire Technology. https://doi.org/10.1023/A:1021723126005

Li, Y., Pimienta, P., Pinoteau, N., \& Tan, K. H. (2019). Effect of aggregate size and inclusion of polypropylene and steel fibers on explosive spalling and pore pressure in ultra-high-performance concrete (UHPC) at elevated temperature. Cement and Concrete Composites, 99(February), 62-71. https://doi.org/10.1016/j.cemconcomp.2019.02.016

Noumowe, A. (2005). Mechanical properties and microstructure of high strength concrete containing polypropylene fibres exposed to temperatures up to $200{ }^{\circ} \mathrm{C}$. Cement and Concrete Research. https://doi.org/10.1016/j.cemconres.2005.03.007

Peng, G. F., Yang, W. W., Zhao, J., Liu, Y. F., Bian, S. H., \& Zhao, L. H. (2006). Explosive spalling and residual mechanical properties of fiber-toughened high-performance concrete subjected to high temperatures. Cement and Concrete Research. https://doi.org/10.1016/j.cemconres.2005.12.014

Poon, C S, Shui, Z. H., \& Lam, L. (2004). Compressive behavior of fiber reinforced high-performance concrete subjected to elevated temperatures. Cement and Concrete Research. https://doi.org/10.1016/j.cemconres.2004.02.011

Poon, Chi Sun, Azhar, S., Anson, M., \& Wong, Y. L. (2001a). Comparison of the strength and durability performance of normal- and high-strength pozzolanic concretes at elevated temperatures. Cement and Concrete Research. https://doi.org/10.1016/S0008-8846(01)00580-4

Poon, Chi Sun, Azhar, S., Anson, M., \& Wong, Y. L. (2001b). Strength and durability recovery of fire-damaged concrete after post-fire-curing. Cement and Concrete Research. https://doi.org/10.1016/S0008-8846(01)00582-8

Rodrigues, J. P. C., Laím, L., \& Correia, A. M. (2010). Behaviour of fiber reinforced concrete columns in fire. Composite Structures. https://doi.org/10.1016/j.compstruct.2009.10.029

Sideris, K. K., Manita, P., \& Chaniotakis, E. (2009). Performance of thermally damaged fibre reinforced concretes. Construction and Building Materials. https://doi.org/10.1016/j.conbuildmat.2008.08.009

Suhaendi, S. L., \& Horiguchi, T. (2006). Effect of short fibers on residual permeability and mechanical properties of hybrid fibre reinforced high strength concrete after heat exposition. Cement and Concrete Research. https://doi.org/10.1016/j.cemconres.2006.05.006

Tanyildizi, H. (2009). Statistical analysis for mechanical properties of polypropylene fiber reinforced lightweight concrete containing silica fume exposed to high temperature. Materials and Design. https://doi.org/10.1016/j.matdes.2008.11.032

TS EN 1015-11. (2000). Mortar Testing Method, Part 11. Measurement of Compressive and Flexural Tensile Strength of Mortar. Turkish Standart, Ankara.

TS EN 1015-3. (2000). Methods of test for mortar for masonry: Part 3. Determination of consistence of fresh mortar (by flow table). Turkish Standart, Ankara.

TS EN 196-1. (2016). TS EN 196-1. Methods of testing cement-part:1 determination of strength. Turkish Standart, Ankara.

TS EN 197-1. (2012). Cement-composition, specifications and conformity criteria-part 1: commmon cements. TSE Ankara, Turkey. 
TS EN 933-1. (2012). Tests for geometrical properties of aggregates - Part 1: Determination of particle size distribution - Sieving method. Turkish Standart, Ankara.

Xiao, J., \& Falkner, H. (2006). On residual strength of high-performance concrete with and without polypropylene fibres at elevated temperatures. Fire Safety Journal. https://doi.org/10.1016/j.firesaf.2005.11.004

Xiao, J., \& König, G. (2004). Study on concrete at high temperature in China - An overview. Fire Safety Journal. https://doi.org/10.1016/S03797112(03)00093-6

Yermak, N., Pliya, P., Beaucour, A. L., Simon, A., \& Noumowé, A. (2017). Influence of steel and/or polypropylene fibres on the behaviour of concrete at high temperature: Spalling, transfer and mechanical properties. Construction and Building Materials, 132 , 240-250. https://doi.org/10.1016/j.conbuildmat.2016.11.120

Yüzer, N., Aköz, F., \& Öztürk, L. D. (2004). Compressive strength-color change relation in mortars at high temperature. Cement and Concrete Research. https://doi.org/10.1016/j.cemconres.2004.01.015

Zeiml, M., Leithner, D., Lackner, R., \& Mang, H. A. (2006). How do polypropylene fibers improve the spalling behavior of in-situ concrete? Cement and Concrete Research. https://doi.org/10.1016/j.cemconres.2005.12.018 